Article

\title{
Effect of Exogenous Application of Amino Acids L-Arginine and Glycine on Maize under Temperature Stress
}

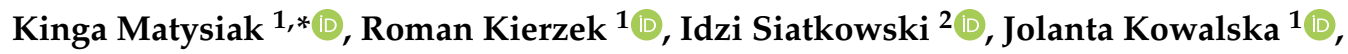 \\ Roman Krawczyk $^{1}{ }^{1}$ and Wojciech Miziniak ${ }^{1}$ (D) \\ 1 Institute of Plant Protection - National Research Institute, ul. Władysława Wegorka 20, \\ 60-318 Poznań, Poland; R.Kierzek@iorpib.poznan.pl (R.K.); J.Kowalska@iorpib.poznan.pl (J.K.); \\ R.Krawczyk@iorpib.poznan.pl (R.K.); W.Miziniak@iorpib.poznan.pl (W.M.) \\ 2 Department of Mathematical and Statistical Methods, Poznan University of Life Sciences, ul. Wojska \\ Polskiego 28, 60-637 Poznan, Poland; idzi.siatkowski@up.poznan.pl \\ * Correspondence: K.Matysiak@iorpib.poznan.pl
}

Received: 7 April 2020; Accepted: 24 May 2020; Published: 28 May 2020

\begin{abstract}
Temperature strongly influences the growth of maize, particularly in the early growth stages. The exogenous application of some amino acids has been proven to have a positive effect on plant growth and development under stressful conditions. The objective of the study was to evaluate the response of maize that was grown under an optimal and stress (fluctuating) temperature to L-Arginine (L-Arg) and Glycine (Gly) application. In the study, it was assumed that the exogenously applied amino acids would alleviate the adverse effects of temperature stress on the maize height, as well as on the biomass of shoots and roots. Ten concentrations of each amino acid from $0.006 \mathrm{mM}$ to $9.0 \mathrm{mM}$ were tested under constant temperature conditions $20-22{ }^{\circ} \mathrm{C} / 23-25{ }^{\circ} \mathrm{C}$ (night/day) an fluctuating stress of rising and dropping temperatures between $12-15^{\circ} \mathrm{C}$ (night) and $30-38^{\circ} \mathrm{C}$ (day). The amino acids were applied to the crop at growth stages V3-V4. In plants that were obtained from seeds pre-treated with L-Arg and Gly, the amino acids increased both the length of radicles and the number of lateral roots. A large discrepancy between the effects of the two amino acids was observed after foliar application. Under optimal thermal conditions, L-Arg increased the mass of shoots and roots by $55-59 \%$. Under stress conditions, root mass was increased even by $100 \%$ when compared to the control plants. The best results were recorded at concentrations of $6 \mathrm{mM}$ and $3 \mathrm{mM}$. Plants that were treated with Gly concentrations generally reached the height of untreated plants or less. It was shown that Gly applied at concentrations of $0.2 \mathrm{mM}$ to $3 \mathrm{mM}$ has a negative effect on the fresh mass of the crop.
\end{abstract}

Keywords: fluctuating temperature; abiotic stress; optimal and stressful conditions; biostimulants

\section{Introduction}

Temperature stress is suggested as a primary growth-limiting factor for most crop plants. It can disturb 'yield potential', which refers to the productivity of a plant when resource capture and utilisation are not limiting, whereas 'stress' is defined as a factor that reduces either resource capture or utilisation [1,2]. It has been proven that the adverse effect of thermal stress conditions largely depends on its severity and duration [3]. Prolonged and even a transitional temperature stress interferes with many metabolic processes in plants. These are mostly evident in the cellular membranes and enzymes, as well as in the whole photosynthetic system.

Elevated temperatures cause a state of dehydration by the rapid loss of water from the plant's surface and reducing the chances of survival, and of further regular growth and development [4]. 
Heat stress is a complex function of the intensity, duration, and rate of increase in temperature. Chilling stress also adversely affects morphological, physiological, biochemical, and molecular changes in plants [5-7]. Most of the injury to plants that is caused by chilling stress is associated with oxidative damage at the cellular level. Additionally, chilling seems to be the major challenging stress among abiotic stresses, because it limits both the productivity and geographical distribution of many crops $[3,8,9]$. A rise and drop in temperature results in protein unfolding and affects multimetric peptide structures. Among the biochemical changes in plants that are caused by temperature stress, and the most conspicuous of these, is the accumulation of reactive oxygen species (ROS) [9-13]. The overproduction of ROS within the cellular environment is determined by the antioxidant system and various compatible solutes can effectively take part in plant stress tolerance [14-16]. Stress conditions, such as salinity, UV radiation, drought, heavy metals, and extreme temperatures, disturb the defence mechanisms in plants, which leads to ROS accumulation inside the cells. Singlet oxygen $\left({ }^{1} \mathrm{O}_{2}\right)$, superoxide $\left(\mathrm{O}_{2}{ }^{-}\right)$, hydrogen peroxide $\left(\mathrm{H}_{2} \mathrm{O}_{2}\right)$, and hydroxyl radical (HO) are toxic to plants and damage proteins, lipids, carbohydrates, and DNA resulting, in extreme cases, in cell death. Excessive ROS accumulation as a result of various environmental stresses is the main reason for agricultural yield loss worldwide [17,18]. The exogenous application of different antioxidants in plants might be helpful in minimizing the harmful effects of stress. Many substances are useful in the way that they provide crucial protection against oxidative damage and, many of them, when applied in small quantities, are also able to enhance the plants' ability to assimilate applied nutrients, or provide benefits to plant development [19]. Biostimulating effect is widely described in many scientific papers on substances such as i.e. -tocoferol, polyamines, L-ascorbate, glutathione, glycine betaine, putrescine, glycine, spermine, spermidyne, salicylic acid, hydrogen peroxide, silicone, alginic acid, polyphenols, and trehalose [3,7,8,15,19-28].

One of the main categories of biostimulants is protein hydrolysates and other $\mathrm{N}$-containing compounds. This group includes free amino acids. In general, protein oxidation by ROS is irreversible, but this does not apply to proteins that are rich in sulphur-containing amino acids (arginine, histidine, proline, threonine, tryptophan). These amino acids, apart from the thiol (-SH) group, also contain a carbonyl group, which inhibits the effects of proteolytic attack [29]. Thus, it has been demonstrated that exogenous application of certain amino acids allows for plants to survive unfavourable stress conditions, and stimulates their further, undisturbed growth and development $[15,19,30-34]$. Some studies have confirmed that, in plants, the most functionally diverse amino acid and a precursor for biosynthesis of nitric oxide and polyamines is L-Arginine $[13,14,16]$. Polyamines and their precursor arginine have been implicated as vital modulators in a variety processes in higher plants, such as growth, physiology, and development, as well as in plant response to various stress factors. It has also been recorded that both endogenous and exogenous arginine play a role in plant stress response $[6,7,35,36]$. Glycine is the simplest amino acid in nature and is one of the most abundant free amino acids in soil. It is more rapidly taken up by plants as compared to other amino acids. However, there have been far fewer studies on the role of the exogenous application of Glycine on plant's growth [24].

Crop species will achieve their highest yields, with the lowest risk of failure, when they are cultivated as close as possible to the specific temperature optimum for each of the plants' developmental stages during the growing season [37]. Maize is a warm season crop and the third most important cereal after wheat and rice. It requires a relatively high temperature optimum $\left(30-35^{\circ} \mathrm{C}\right)$ for growth and development. In climates with mid-summer, the optimum growth in maize crop varies between $21^{\circ} \mathrm{C}$ and $27^{\circ} \mathrm{C}$. The temperature below $12-15^{\circ} \mathrm{C}$ can damage the young plant, mostly by growth and development inhibition. Maize plants are the most sensitive to chilling at early growth stages $[8,38,39]$. It has been proven that free amino acid contents were decreased with increasing stress in maize plants [33].

The objective of the present study was to evaluate the response of maize grown under optimal and stress (rising and dropping) temperature to L-Aginine and Glycine application. The amino acids that were used in the study differed considerably in terms of their structure and function: L-Arg is a precursor of polyamines, and Gly, which is a chlorophyll precursor, enhances photosynthesis. In the 
study, it was hypothesized that the exogenously applied amino acids would alleviate the adverse effects of temperature stress on maize growth and the mass of shoots and roots. There have been no reports on the foliar application of L-Arginine and Glycine under fluctuating thermal conditions. Moreover, the scientific literature lacks publications regarding the effect of these amino acids on such an economically important plant as maize.

\section{Materials and Methods}

In the Institute of Plant Protection-National Research Institute in Poznan (Poland), four cycles of laboratory and glasshouse experiments were conducted. They aimed at assessing the effect of amino acids on the initial growth of maize. The fodder cultivar Wiarus, chosen for the experiments, was characterized by very good early vigour that is based on the breeding tests (Plant Breeding Company Ltd. Smolice). The experiments involved the application of two amino acids: L-Arginine and Glycine.

\subsection{Characteristics of Amino Acids}

L-Arginine (L-Arg) was used as L-Arginine preparation (High Purity Grade); ARG005.500; $\mathrm{C}_{2} \mathrm{H}_{14}{\mathrm{~N} 4 \mathrm{O}_{2}}_{2}$; MW 174.20; Purity min. 98.5\%; Residue on ignition: $<0.3 \%$; Heavy metals: $<0.0015$; Sulfate $(\mathrm{SO} 4)<0.03 \%$; Chloride $<0.05 \%$; Iron $<0.003 \%$; Manufacturer BioShop ${ }^{\circledR}$ Canada Inc., Burlington, ON, Canada.

Glycine (Gly) was used as Glycine preparation (Biotechnology Grade); GLN0001.500; $\mathrm{C}_{2} \mathrm{H}_{5} \mathrm{NO}_{2}$; MW 75.07; Purity min. 99.0\%; Solubility (10\% water): clear/colourless; Heavy metals (as $\mathrm{Pb})<0.002 \%$; DNase, ENase and Protease activity: non-detected; and, Manufacturer BioShop ${ }^{\circledR}$ Canada Inc.

\subsection{Laboratory Experiments}

Laboratory experiments were preliminary trials that were undertaken to confirm a useful selection of amino acid concentrations for glasshouse experiments. The laboratory experiments used a commercial toxicity bioassay-PhytotoxkitTM test (Phytotoxkit ${ }^{\text {TM }}$ 2004, MicroBioTests Inc, Gent, Belgium). The test was based on measuring the germination and growth of the plant radicle after three days of exposure to experimental treatments. The Phytotoxkit makes use of flat and shallow transparent test plates composed of two compartments, with the lower one containing soil saturated to water-holding capacity. Maize seeds were soaked for $24 \mathrm{~h}$ in distilled water solutions of L-Arginine and Glycine. Each amino acid was applied in ten concentrations: $0.006 \mathrm{mM}, 0.003 \mathrm{mM}, 0.06 \mathrm{mM}$, $0.2 \mathrm{mM}, 0.3 \mathrm{mM}, 0.6 \mathrm{mM}, 2 \mathrm{mM}, 3 \mathrm{mM}, 6 \mathrm{mM}$, and $9 \mathrm{mM}$. There was also control treatment involving seeds soaked in pure distilled water. In the next phase, the seeds were transferred to plastic test plates. In the lower compartment of each plate, $90 \mathrm{~mL}$ of quartz sand $(\varnothing 0.6-0.8 \mathrm{~mm})$ and $50 \mathrm{~mL}$ of water to obtain $100 \%$ water saturation of the sand were applied. The experiment was carried out in four replications. Ten seeds (per replicate) were positioned at equal distances near the middle ridge of each test plate and in two rows on a black filter paper. The test plates were closed and placed vertically in a holder and incubated in dark conditions at $25{ }^{\circ} \mathrm{C}$ for three days. After the incubation period, digital pictures were taken and both the length of the radicles (main root) and the number of lateral roots were estimated while using a software image tool 3.0 UTHSCSA.

\subsection{Glasshouse Experiments}

Maize seeds were sown in plastic pots $\left(17 \mathrm{~m}^{-2}\right.$ diameter). Horticultural soil mixed with sand in a ratio of $3: 1$ was used as the substrate for the experiments. The soil contained $1.89 \%$ organic matter and had a pH of 6.2. Twenty seeds were planted in each pot. After emergence, the plants were thinned to 10 plants per pot. Amino acids were applied to three-four leaves of plants (the growth stage V3-V4). The experiment involved 11 combinations: 10 sprayed with amino acid solutions and the control (distilled water). The experiments were carried out in three series and eight replications (88 pots for each series). The pots were randomly allocated and the series followed one after the other. Ten water 
solutions of each amino acid (L-Arginine and Glycine) were tested at concentrations of $0.006 \mathrm{mM}$, $0.003 \mathrm{mM}, 0.06 \mathrm{mM}, 0.2 \mathrm{mM}, 0.3 \mathrm{mM}, 0.6 \mathrm{mM}, 2 \mathrm{mM}, 3 \mathrm{mM}, 6 \mathrm{mM}$, and $9 \mathrm{mM}$. The application was performed with a greenhouse sprayer equipped with a TeeJet TT 11002 spray nozzle at a pressure of $0.3 \mathrm{MPa}$. In the experiments, the greenhouse conditions included a temperature of $20-22^{\circ} \mathrm{C}$ (night) and $23-25^{\circ} \mathrm{C}$ (day) and a $16 / 8$-h day-night photoperiod with a light intensity of $\approx 150 \mu \mathrm{mol} \cdot \mathrm{m}^{-2} \cdot \mathrm{s}^{-1}$ and a relative humidity of $60-70 \%$. After spraying, all of the plants were divided into two groups and one group (44 pots) was moved to a chamber where the temperature was subject to daily fluctuations. The temperature oscillated between $12-15^{\circ} \mathrm{C}$ (night) and $30-38^{\circ} \mathrm{C}$ (day) and the relative humidity varied from $50 \%$ to $85 \%$. Figure 1 presents the mean temperature in all of the experiment series. Other experimental conditions (light, water supply) remained unchanged. The temperature measurements were performed while using a HOBO Temperature/Relative Humidity Data Logger with an accuracy of $\pm 0.7^{\circ} \mathrm{C}$. The remaining plants were kept in optimal conditions for growth and development. After 14 days, the height and the mass of shoots and roots of plants from optimal and stressed conditions were estimated (at the growth stage V8).

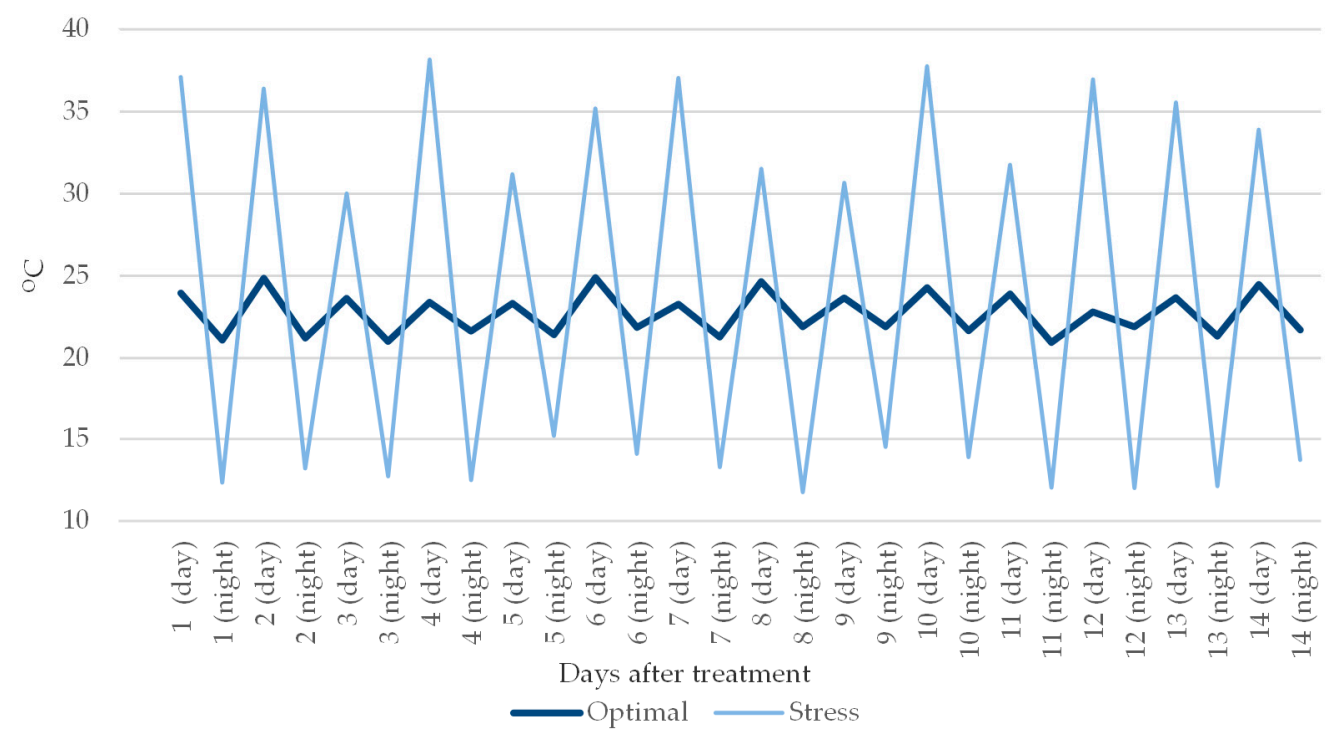

Figure 1. Average day/night temperature during the experiments under optimal and stress conditions.

\subsection{Statistical Analysis}

The results of the laboratory experiments were subjected to statistical analysis in accordance with the two-factor ANOVA model by means of FR-ANALWAR-4.3 software. The significance of differences was assessed with Tukey's confidence half-interval at a significance level of $p=0.05$. All statistical analyses for the greenhouse experiments were carried out in R version 3.6.2 [40].

\section{Results}

\subsection{Germination and Initial Growth of Maize (Pre-Treated Seeds)}

The seeds soaked in the L-Arginine (L-Arg) and Glycine (Gly) solutions germinated at the same level as the seeds soaked only in distilled water $(100 \%)$. The length of the longest radicle after three days of incubation in dark conditions was obtained for concentrations of L-Arg $0.2 \mathrm{mM}$ and $0.3 \mathrm{mM}$ (Table 1). L-Arg applied at concentrations of $0.2 \mathrm{mM}, 0.3 \mathrm{mM}$ and $0.6 \mathrm{mM}$ increased the number of lateral roots. In the case of Gly, only concentrations of $0.6 \mathrm{mM}$ and $2.0 \mathrm{mM}$ significantly affected the length of the radicle (Table 2). Low concentrations of Gly from $0.006 \mathrm{mM}$ to $0.06 \mathrm{~m}, \mathrm{M}$ as well as from $2 \mathrm{mM}$ to $9 \mathrm{mM}$, did not affect the increase in lateral roots and a beneficial effect on this trait was reported for the concentrations of $0.2 \mathrm{mM}$ and $0.3 \mathrm{mM}$. 
Table 1. Influence of L-Arginine on initial root growth of maize (soaked seeds).

\begin{tabular}{ccc}
\hline L-Arginine Concentration $\mathbf{m M}$ & Lenght of Radicle ${ }^{* *}, \mathbf{c m}$ & Number of Lateral Roots $^{* *}$, pc. \\
\hline Control $\mathrm{H}_{2} \mathrm{O}$ & $7.6 \pm 0.12 \mathrm{bc}{ }^{*}$ & $2.7 \pm 0.37 \mathrm{bc}$ \\
0.006 & $7.5 \pm 0.22 \mathrm{bc}$ & $3.5 \pm 0.15 \mathrm{ab}$ \\
0.003 & $8.5 \pm 0.08 \mathrm{ab}$ & $2.9 \pm 0.20 \mathrm{~b}$ \\
0.06 & $8.1 \pm 0.25 \mathrm{abc}$ & $2.9 \pm 0.12 \mathrm{~b}$ \\
0.2 & $10.3 \pm 0.34 \mathrm{a}$ & $4.9 \pm 0.29 \mathrm{a}$ \\
0.3 & $10.2 \pm 0.28 \mathrm{a}$ & $4.1 \pm 0.33 \mathrm{a}$ \\
0.6 & $9.8 \pm 0.17 \mathrm{ab}$ & $4.4 \pm 0.15 \mathrm{a}$ \\
2.0 & $9.1 \pm 0.25 \mathrm{ab}$ & $3.0 \pm 0.22 \mathrm{~b}$ \\
3.0 & $7.0 \pm 0.67 \mathrm{bc}$ & $2.4 \pm 0.31 \mathrm{bc}$ \\
6.0 & $8.1 \pm 0.25 \mathrm{abc}$ & $2.6 \pm 0.25 \mathrm{bc}$ \\
9.0 & $5.9 \pm 0.10 \mathrm{c}$ & $1.9 \pm 0.38 \mathrm{c}$ \\
\hline
\end{tabular}

${ }^{*}$ Mean values \pm SD. Means with different letters in the column are significantly different according to Tukey's test at $p<0.05 .{ }^{* *}$ Means for 40 plants.

Table 2. Influence of Glycine on the initial root growth of maize (soaked seeds).

\begin{tabular}{ccc}
\hline Glycine Concentration $\mathbf{~ m M}$ & Lenght of Radicle ${ }^{* *}, \mathbf{c m}$ & Number of Lateral Roots ${ }^{* *}$, pc. \\
\hline Control $\mathrm{H}_{2} \mathrm{O}$ & $8.4 \pm 0.22 \mathrm{~b}{ }^{*}$ & $1.9 \pm 0.21 \mathrm{~b}$ \\
0.006 & $8.1 \pm 0.34 \mathrm{~b}$ & $1.7 \pm 0.13 \mathrm{~b}$ \\
0.003 & $8.4 \pm 0.45 \mathrm{~b}$ & $1.3 \pm 0.19 \mathrm{~b}$ \\
0.06 & $8.1 \pm 0.13 \mathrm{~b}$ & $1.7 \pm 0.13 \mathrm{~b}$ \\
0.2 & $8.7 \pm 0.21 \mathrm{~b}$ & $2.5 \pm 0.14 \mathrm{a}$ \\
0.3 & $9.4 \pm 0.17 \mathrm{ab}$ & $2.4 \pm 0.25 \mathrm{a}$ \\
0.6 & $10.3 \pm 0.21 \mathrm{a}$ & $2.0 \pm 0.17 \mathrm{ab}$ \\
2.0 & $10.1 \pm 0.21 \mathrm{a}$ & $1.8 \pm 0.13 \mathrm{~b}$ \\
3.0 & $8.8 \pm 0.41 \mathrm{ab}$ & $1.5 \pm 0.26 \mathrm{~b}$ \\
6.0 & $8.9 \pm 0.11 \mathrm{ab}$ & $1.8 \pm 0.16 \mathrm{~b}$ \\
9.0 & $8.8 \pm 0.06 \mathrm{ab}$ & $1.3 \pm 0.18 \mathrm{~b}$ \\
\hline
\end{tabular}

${ }^{*}$ Mean values \pm SD. Means with different letters in the column are significantly different according to Tukey's test at $p<0.05 .{ }^{* *}$ Means for 40 plants.

\subsection{General Differences between the Amino Acid Effects}

The verification of hypotheses about the significant impact of stress, amino acids, and their interactions on mass of roots, mass of shots and height of plants was performed while using a two-factor analysis of variance with interaction (Table 3). Stress treatment and amino acid effect statistically significantly affected the number of mass of roots, mass of shoots, and height of plants. The interaction is also statistically significant, i.e. the application of amino acids affects the stress response (Table 3).

Table 3. The effect of stress, amino acid and their interaction on mass of roots, mass of shoots, and height of plants.

\begin{tabular}{|c|c|c|c|c|c|c|}
\hline \multirow[b]{2}{*}{ Source } & \multicolumn{2}{|c|}{ Fresh Mass of Roots } & \multicolumn{2}{|c|}{ Fresh Mass of Shoots } & \multicolumn{2}{|c|}{ Height of Plants } \\
\hline & MSq & $p$-Value & MSq & $p$-Value & MSq & $p$-Value \\
\hline Stress treatment & 328.2 & $<0.0001^{* * *}$ & 1495 & $<0.0001^{* * *}$ & 10422 & $<0.0001^{* * *}$ \\
\hline Amino acid & 738.2 & $<0.0001^{* * *}$ & 90980 & $<0.0001^{* * *}$ & 213915 & $<0.0001^{* * *}$ \\
\hline Conditions *Amino acid & 891.4 & $<0.0001^{* * *}$ & 69705 & $<0.0001^{* * *}$ & 144701 & $<0.0001^{* * *}$ \\
\hline Residuals & 2.3 & & 72 & & 188 & \\
\hline
\end{tabular}

Signs: Source-source of variation, Msq-mean square, Signif. codes: ${ }^{‘ * * * \prime}<0.001$.

The reaction of maize sprayed with amino acids varied, depending on the growing conditions. Plants growing under optimal conditions showed significant differences in both the fresh mass of shoots and fresh mass of roots after L-Arg applications in some concentrations (Tables 4 and 5). On the 
other hand, for plants growing under stress, statistically significant differences were only recorded for root mass (Tables 6 and 7). The completely adverse results were recorded for Gly, where under optimal conditions, the differences between the treatments only occurred for plant height (Tables 8 and 9), and under stress conditions for all traits being examined, but only for some specific concentrations (Tables 10 and 11).

Table 4. ANOVA test for L-Arginine under optimal thermal conditions.

\begin{tabular}{|c|c|c|c|c|c|}
\hline Source & Df & Sum Sq & Mean Sq & $F$ Value & $\operatorname{Pr}(>F)$ \\
\hline \multicolumn{6}{|c|}{ Height of maize plants } \\
\hline Concentrations & 10 & 8288 & 828.8 & 5.379 & $<0.0001^{* * *}$ \\
\hline Residuals & 429 & 66097 & 154.1 & - & - \\
\hline \multicolumn{6}{|c|}{ Mass of maize shoots } \\
\hline Concentrations & 10 & 3260 & 326.0 & 7.939 & $<0.0001^{* * *}$ \\
\hline Residuals & 429 & 17619 & 41.1 & - & - \\
\hline \multicolumn{6}{|c|}{ Mass of maize roots } \\
\hline Concentrations & 10 & 90.1 & 9.01 & 5.617 & $<0.0001^{* * *}$ \\
\hline Residuals & 429 & 686.5 & 1.604 & - & - \\
\hline
\end{tabular}

Signif. codes: ${ }^{* * *} p<0.001$.

Table 5. Influence of L-Arginine on maize growth under optimal thermal conditions.

\begin{tabular}{cccc}
\hline $\begin{array}{c}\text { L-Argnine } \\
\text { Concentration } \mathbf{~ m M}\end{array}$ & Height of Plants ${ }^{* *}, \mathbf{c m}$ & Fresh Mass of Shoots ${ }^{* *}, \mathbf{g}$ & Fresh Mass of Roots ${ }^{* *}, \mathbf{g}$ \\
\hline Control $\mathrm{H}_{2} \mathrm{O}$ & $74.38 \pm 10.20 \mathrm{abcd}{ }^{*}$ & $13.94 \pm 4.33 \mathrm{bc}$ & $2.59 \pm 1.22 \mathrm{c}$ \\
0.006 & $70.93 \pm 14.92 \mathrm{~d}$ & $13.23 \pm 4.62 \mathrm{c}$ & $3.20 \pm 1.12 \mathrm{abc}$ \\
0.003 & $76.30 \pm 10.94 \mathrm{abcd}$ & $15.13 \pm 5.74 \mathrm{bc}$ & $3.08 \pm 0.95 \mathrm{bc}$ \\
0.06 & $72.83 \pm 9.95 \mathrm{~cd}$ & $13.48 \pm 5.81 \mathrm{c}$ & $3.03 \pm 1.41 \mathrm{bc}$ \\
0.2 & $74.10 \pm 12.15 \mathrm{bcd}$ & $15.30 \pm 7.16 \mathrm{bc}$ & $3.22 \pm 1.29 \mathrm{abc}$ \\
0.3 & $80.70 \pm 12.78 \mathrm{abc}$ & $21.28 \pm 6.13 \mathrm{a}$ & $3.70 \pm 1.47 \mathrm{ab}$ \\
0.6 & $82.28 \pm 13.83 \mathrm{ab}$ & $18.19 \pm 6.87 \mathrm{ab}$ & $3.37 \pm 1.16 \mathrm{abc}$ \\
2.0 & $83.30 \pm 11.06 \mathrm{a}$ & $21.31 \pm 7.49 \mathrm{a}$ & $4.01 \pm 1.31 \mathrm{a}$ \\
3.0 & $82.48 \pm 13.31 \mathrm{ab}$ & $18.29 \pm 7.44 \mathrm{ab}$ & $3.72 \pm 1.46 \mathrm{ab}$ \\
6.0 & $82.30 \pm 14.47 \mathrm{ab}$ & $16.32 \pm 7.40 \mathrm{bc}$ & $2.84 \pm 1.25 \mathrm{bc}$ \\
9.0 & $80.73 \pm 11.75 \mathrm{abc}$ & $16.42 \pm 6.53 \mathrm{bc}$ & $2.49 \pm 1.18 \mathrm{c}$ \\
\hline
\end{tabular}

* Mean values \pm SD. Means with different letters in the column are significantly different according to Tukey's test at $p<0.05$. ${ }^{* *}$ Means for 120 plants.

Table 6. ANOVA test for L-Arginine under stressed thermal conditions.

\begin{tabular}{|c|c|c|c|c|c|}
\hline Source & Df & Sum Sq & Mean Sq & $F$ Value & $\operatorname{Pr}(>F)$ \\
\hline \multicolumn{6}{|c|}{ Height of maize plants } \\
\hline Concentrations & 10 & 2547 & 254.7 & 1.164 & 0.314 \\
\hline Residuals & 422 & 92376 & 218.9 & - & - \\
\hline \multicolumn{6}{|c|}{ Mass of maize shoots } \\
\hline Concentrations & 10 & 1557 & 155.7 & 1.275 & 0.242 \\
\hline Residuals & 421 & 51410 & 122.1 & - & - \\
\hline \multicolumn{6}{|c|}{ Mass of maize roots } \\
\hline Concentrations & 10 & 152.1 & 15.211 & 3.105 & $<0.001^{* * *}$ \\
\hline Residuals & 395 & 1934.9 & 4.899 & - & - \\
\hline
\end{tabular}


Table 7. Influence of L-Arginine on maize growth under stressed thermal conditions.

\begin{tabular}{cc}
\hline L-Argnine Concentration $\mathbf{m M}$ & Mass of Roots $^{* *}, \mathbf{g}$ \\
\hline Control $\mathrm{H}_{2} \mathrm{O}$ & $2.21 \pm 0.93 \mathrm{~b}{ }^{*}$ \\
0.006 & $4.32 \pm 2.74 \mathrm{a}$ \\
0.003 & $3.73 \pm 1.94 \mathrm{ab}$ \\
0.06 & $4.11 \pm 1.86 \mathrm{a}$ \\
0.2 & $4.00 \pm 2.60 \mathrm{a}$ \\
0.3 & $3.78 \pm 1.91 \mathrm{ab}$ \\
0.6 & $3.55 \pm 2.38 \mathrm{ab}$ \\
2.0 & $4.02 \pm 2.42 \mathrm{a}$ \\
3.0 & $4.40 \pm 2.38 \mathrm{a}$ \\
6.0 & $4.55 \pm 2.55 \mathrm{a}$ \\
9.0 & $3.65 \pm 2.23 \mathrm{ab}$
\end{tabular}

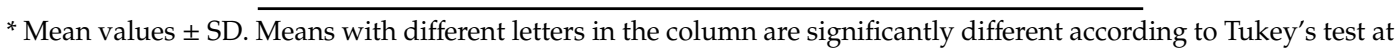
$p<0.05 .{ }^{* *}$ Means for 120 plants.

Table 8. ANOVA test for Glycine under optimal thermal conditions.

\begin{tabular}{|c|c|c|c|c|c|}
\hline Source & Df & Sum Sq & Mean Sq & $F$ Value & $\operatorname{Pr}(>F)$ \\
\hline \multicolumn{6}{|c|}{ Height of maize plants } \\
\hline Concentrations & 10 & 4830 & 483.0 & 2.414 & $0.008 * *$ \\
\hline Residuals & 428 & 85636 & 200.1 & & \\
\hline \multicolumn{6}{|c|}{ Mass of maize shoots } \\
\hline Concentrations & 10 & 1655 & 165.5 & 1.524 & 0.128 \\
\hline Residuals & 428 & 46482 & 108.6 & & \\
\hline \multicolumn{6}{|c|}{ Mass of maize roots } \\
\hline Concentrations & 10 & 19.3 & 1.929 & 1.122 & 0.344 \\
\hline Residuals & 428 & 736.0 & 1.720 & & \\
\hline
\end{tabular}

Table 9. Influence of Glycine on maize growth under optimal thermal conditions.

\begin{tabular}{cc}
\hline Glycine Concentration $\mathbf{m M}$ & Height of Plants ${ }^{* *}, \mathbf{c m}$ \\
\hline Control $\mathrm{H}_{2} \mathrm{O}$ & $70.98 \pm 18.55 \mathrm{ab}{ }^{*}$ \\
0.006 & $71.93 \pm 10.84 \mathrm{ab}$ \\
0.003 & $78.93 \pm 13.48 \mathrm{a}$ \\
0.06 & $75.41 \pm 12.88 \mathrm{ab}$ \\
0.2 & $73.70 \pm 14.68 \mathrm{ab}$ \\
0.3 & $79.05 \pm 13.66 \mathrm{a}$ \\
0.6 & $76.28 \pm 14.79 \mathrm{ab}$ \\
2.0 & $71.70 \pm 10.32 \mathrm{ab}$ \\
3.0 & $71.18 \pm 11.81 \mathrm{ab}$ \\
6.0 & $77.90 \pm 16.14 \mathrm{ab}$ \\
9.0 & $69.28 \pm 16.24 \mathrm{~b}$
\end{tabular}

* Mean values \pm SD. Means with different letters in the column are significantly different according to Tukey's test at $p<0.05$. ${ }^{* *}$ Means for 120 plants.

\subsubsection{L-Arginine Effect on Maize under Optimal and Stress Conditions}

The analysis of L-Arg effect on plants growing under optimum conditions did not reveal any statistically significant differences in the height of plants between the plants that were treated with the amino acid solution, and the control, where distilled water was used (Table 5). However, there were differences between the L-Arg doses studied. The highest plants were obtained with the concentration of $2 \mathrm{mM}$, and the lowest with $0.006 \mathrm{mM}$. The difference in plant height between these experiment objects was $15 \%$. Doses of L-Arg $0.3 \mathrm{mM}$ and $2.0 \mathrm{mM}$ had a more favourable effect on the mass of 
maize shoots. L-Arg applied at a concentration of $0.3 \mathrm{mM}$ and $2 \mathrm{mM}$ increased the mass of shoots by $59 \%$. Under optimal conditions, amino acid applied at concentrations of 0.006 to $0.2 \mathrm{mM}$ did not affect the mass of plant shoots, and the obtained results did not statistically differ. The concentration of $2 \mathrm{mM}$ also proved to be the most effective in increasing root mass and in this treatment an increase in root mass by $55 \%$ was achieved.

Table 10. ANOVA test for Glycine under thermal stress.

\begin{tabular}{|c|c|c|c|c|c|}
\hline Source & Df & Sum Sq & Mean Sq & F Value & $\operatorname{Pr}(>\mathrm{F})$ \\
\hline \multicolumn{6}{|c|}{ Height of maize plants } \\
\hline Concentrations & 10 & 13168 & 1317 & 10.13 & $<0.001^{* * *}$ \\
\hline Residuals & 427 & 55510 & 130 & & \\
\hline \multicolumn{6}{|c|}{ Mass of maize shoots } \\
\hline Concentrations & 10 & 708.1 & 70.81 & 12.92 & $<0.001 * * *$ \\
\hline Residuals & 427 & 2340.2 & 5.48 & & \\
\hline \multicolumn{6}{|c|}{ Mass of maize roots } \\
\hline Concentrations & 10 & 17.2 & 1.723 & 2.135 & $0.021 *$ \\
\hline Residuals & 427 & 344.6 & 0.807 & & \\
\hline
\end{tabular}

Table 11. Influence of Glycine on maize growth under thermal stress.

\begin{tabular}{cccc}
\hline $\begin{array}{c}\text { Glycine } \\
\text { Concentration } \mathbf{~ m M}\end{array}$ & Height of Plants ${ }^{* *}, \mathbf{c m}$ & Fresh Mass of Shoots ${ }^{* *}, \mathbf{g}$ & Fresh Mass of Roots ${ }^{* *}, \mathbf{g}$ \\
\hline Control $\mathrm{H}_{2} \mathrm{O}$ & $65.95 \pm 9.41 \mathrm{ab} \mathrm{b}^{*}$ & $5.27 \pm 2.37 \mathrm{ab}$ & $0.95 \pm 0.40 \mathrm{ab}$ \\
0.006 & $73.05 \pm 13.33 \mathrm{a}$ & $6.77 \pm 2.98 \mathrm{a}$ & $1.30 \pm 0.54 \mathrm{ab}$ \\
0.003 & $53.65 \pm 10.60 \mathrm{e}$ & $2.28 \pm 1.11 \mathrm{e}$ & $0.94 \pm 0.41 \mathrm{ab}$ \\
0.06 & $65.05 \pm 5.42 \mathrm{ab}$ & $4.58 \pm 2.63 \mathrm{bcd}$ & $1.01 \pm 0.50 \mathrm{ab}$ \\
0.2 & $55.20 \pm 10.31 \mathrm{de}$ & $2.92 \pm 1.50 \mathrm{de}$ & $0.89 \pm 0.30 \mathrm{~b}$ \\
0.3 & $57.95 \pm 12.99 \mathrm{bcde}$ & $3.25 \pm 2.57 \mathrm{cde}$ & $0.87 \pm 0.30 \mathrm{~b}$ \\
0.6 & $58.40 \pm 12.33 \mathrm{bcde}$ & $3.68 \pm 2.40 \mathrm{bcde}$ & $0.86 \pm 0.36 \mathrm{~b}$ \\
2.0 & $59.26 \pm 6.79 \mathrm{bcde}$ & $3.14 \pm 0.71 \mathrm{cde}$ & $0.99 \pm 0.29 \mathrm{ab}$ \\
3.0 & $55.90 \pm 11.75 \mathrm{cde}$ & $3.05 \pm 1.61 \mathrm{de}$ & $1.54 \pm 2.69 \mathrm{a}$ \\
6.0 & $63.00 \pm 11.69 \mathrm{bcde}$ & $4.76 \pm 2.44 \mathrm{bc}$ & $1.13 \pm 0.39 \mathrm{ab}$ \\
9.0 & $63.55 \pm 16.42 \mathrm{bc}$ & $5.07 \pm 3.70 \mathrm{~b}$ & $1.01 \pm 0.43 \mathrm{ab}$ \\
\hline
\end{tabular}

${ }^{*}$ Mean values \pm SD. Means with different letters in the column are significantly different according to Tukey's test at $p<0.05$.* Means for 120 plants.

In stressful conditions, the only feature influenced by L-Arg was the mass of maize roots. Six out of ten concentrations of L-Arg $(0.006 \mathrm{mM}, 0.2 \mathrm{mM}, 2.0 \mathrm{mM}, 3.0 \mathrm{mM}$, and $6.0 \mathrm{mM})$ had a positive effect on this trait (Table 7). The smallest mass gain was $60 \%$ for a concentration of $9 \mathrm{mM}$. The highest root mass was obtained by plants treated with a concentration of $3 \mathrm{mM}$ and $6 \mathrm{mM}$. When compared to the control, the maize increased in root mass by $100-106 \%$, respectively.

\subsubsection{Glycine Effect on Maize under Optimal and Stress Conditions}

No significant changes with regard to the control were recorded under favourable conditions for the growth and development of maize (Table 9).

Under stress conditions, Gly did not show any beneficial effect on increasing the height of maize plants, and for most of the amino acid concentrations studied, even adverse effects on this trait were proven (Table 11). Plants that were treated with other Gly concentrations reached the height of untreated plants or less. In the case of concentrations of $0.2 \mathrm{mM}$ and $0.003 \mathrm{mM}$, the plants were $16-18 \%$ shorter than the control ones. By analysing the fresh mass of the plants, it was proven that Gly has a negative effect on this trait. The reduction in shoot mass caused by the application of Gly depended on the concentration used. Fresh mass of maize shoots lower than in untreated plants was recorded at 
the following amino acid concentrations: $0.003 \mathrm{mM}, 0.2 \mathrm{mM}, 0.3 \mathrm{mM}, 2.0 \mathrm{mM}$, and $3.0 \mathrm{mM}$. However, no significant differences in mass were observed between these concentrations. No adverse effect of Gly on the mass of the maize root system was noted.

\subsubsection{The Multidimensional Dependencies between Amino Acids and Experimental Conditions}

Principal Component Analysis (PCA) was used to illustrate, in the form of PCA biplots [37], the relationship between the variables observed (mass of roots, mass of shoots, height of plants) and between optimal and stress conditions. In both cases (for Gly and L-Arg), the first two principal components explain more than $85 \%$ of the total variability in the variables under analysis (mass of roots, mass of shoots, height of plants). The points represent the measurements, and arrows, whose length indicates the amount of variance accounted for by each variable, represent the variables. In the biplot, the distance between the points shows the similarity in the observations. The projection of a point on a line represents the contribution of a certain variable to the measurements of that specific observation. From these biplots (Figures 2-4), we can see the strong positive correlation between the mass of shoots and the height of plants. Conversely, the mass of roots and the height of plants are not correlated. The correlation has been presented as the angle between lines representing two variables. There were differences between the cases under observation and the response to the conditions (optimal and stress). This can be observed in Figures 2 and 3 as grouping clusters of stress and optimal conditions.

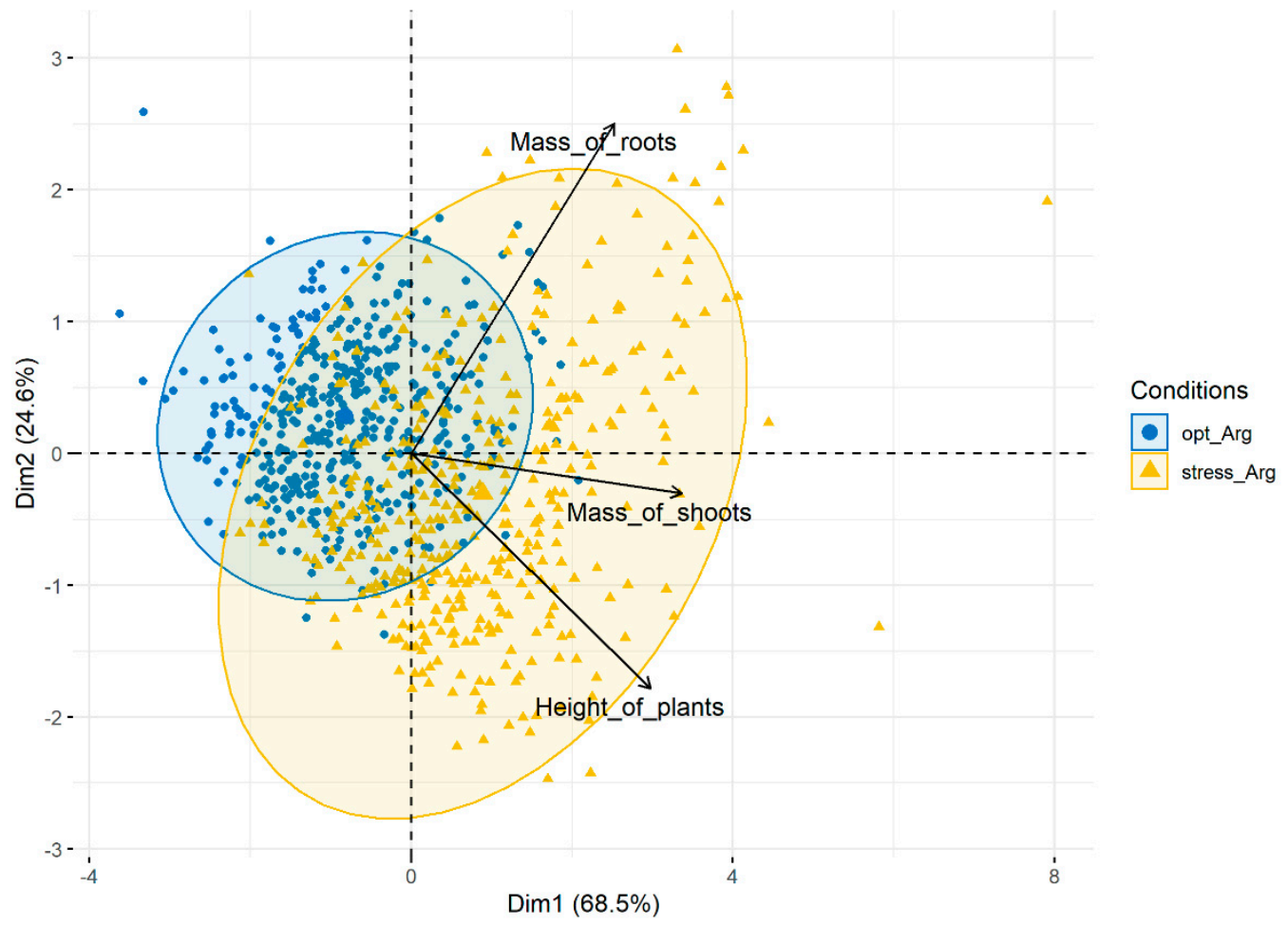

Figure 2. Principal Component Analysis (PCA) biplot of the fresh mass of roots, the fresh mass of shoots and the height of plants for L-Arginine. Cases are grouped by the conditions applied (optimal and stress). 


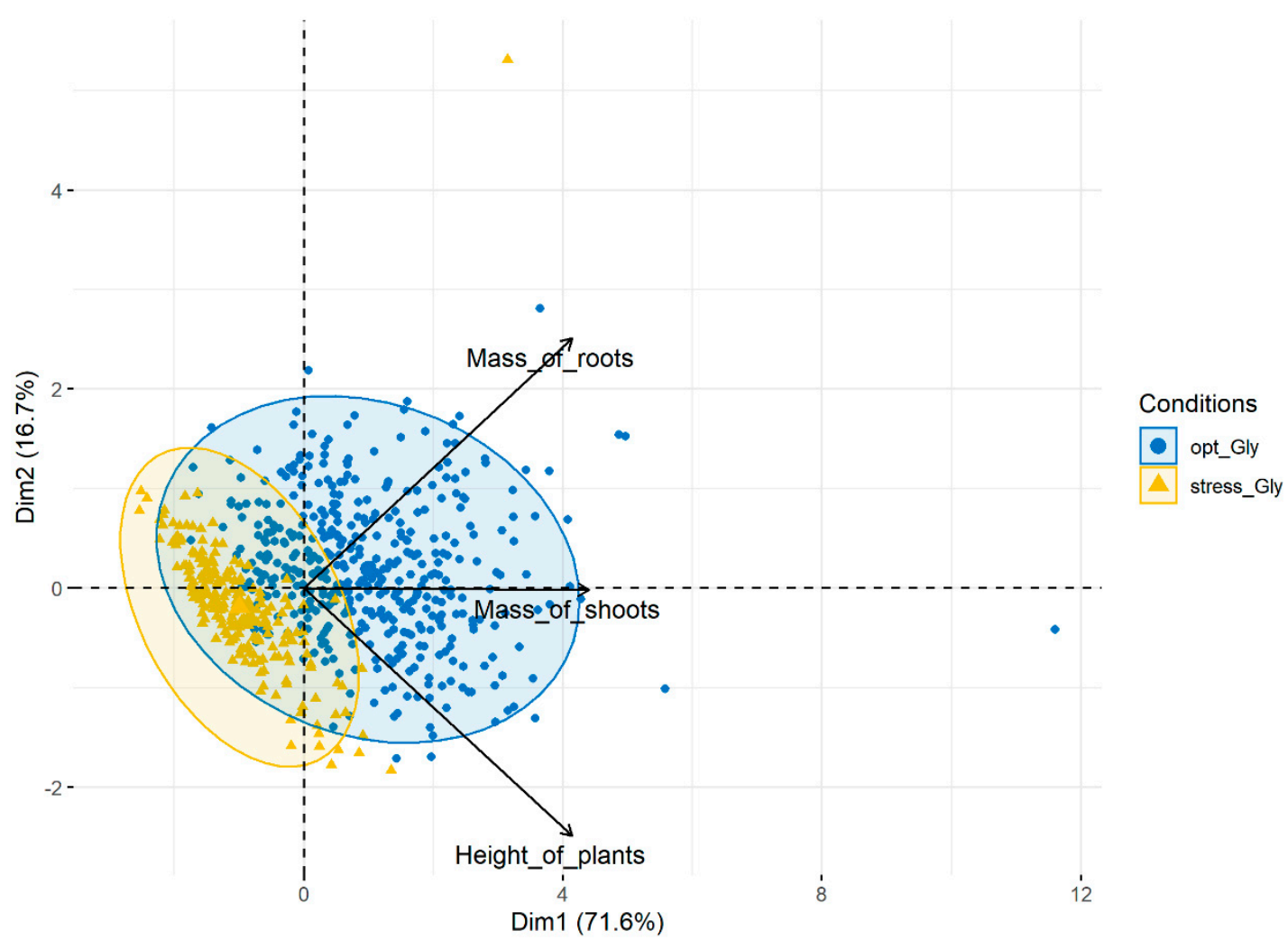

Figure 3. PCA biplot of the fresh mass of roots, the fresh mass of shoots and the height of plants for Glycine. Cases are grouped by the conditions applied (optimal and stress).

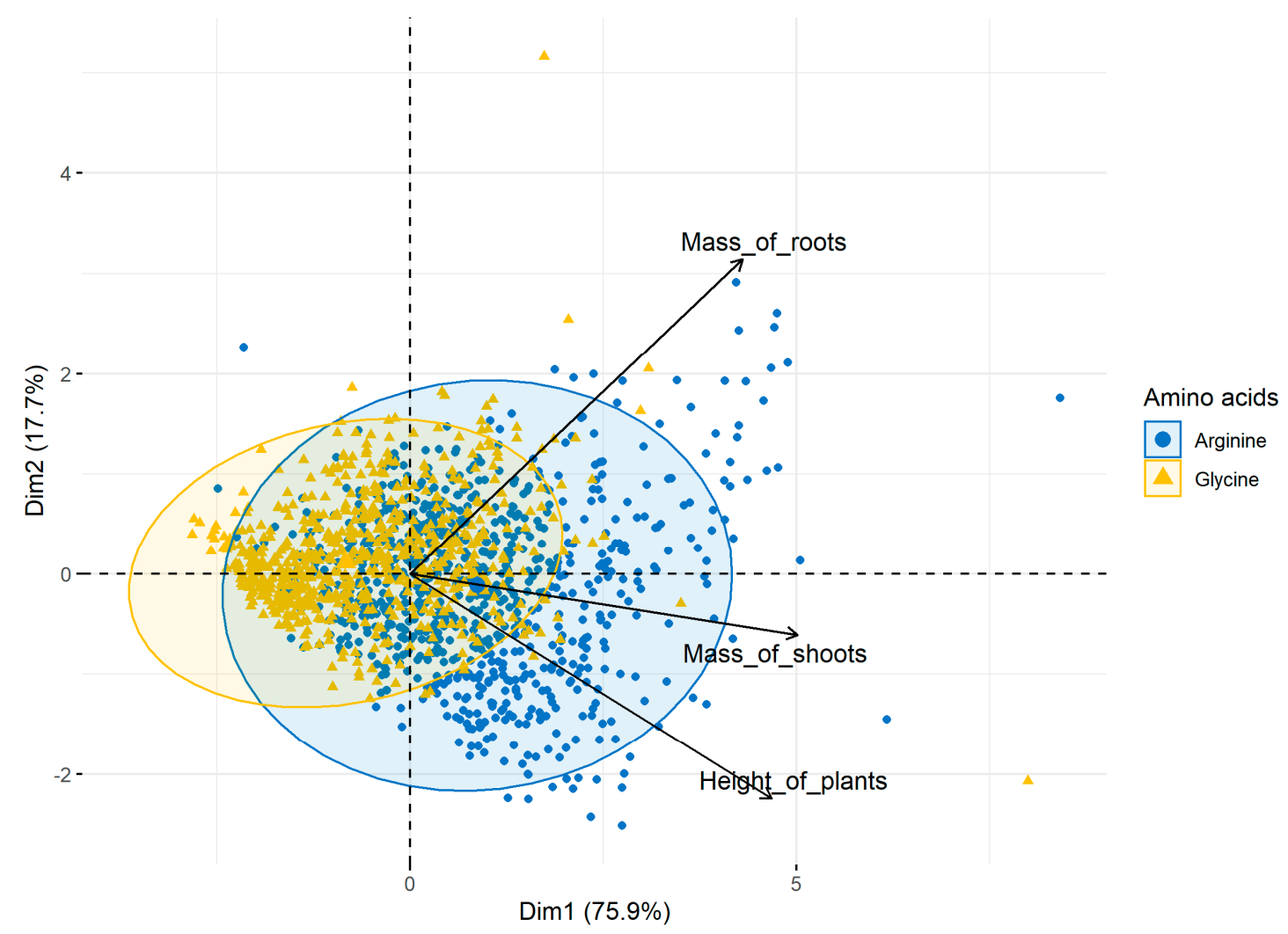

Figure 4. PCA biplot of the fresh mass of roots, the fresh mass of shoots and the height of plants. Cases are grouped by the amino acid applied (L-Arginine and Glycine). 
It is also worth pointing out that, in the case of Gly, the results for the variables, such as the mass of roots, the mass of shoots, and the height of plants, are greater for optimal conditions than for stressful ones. The reverse is true for L-Arg. The same can be seen in Figure 4, where the results for the variables observed are much higher for stress conditions for L-Arg than for stress conditions for Gly. For the optimal conditions, both variables have similar results.

From Figure 3, where cases are grouped by amino acid, we can conclude that the results for the variables, such as the mass of roots, the mass of shoots, and the height of plants are greater for L-Arg than for Gly.

Moreover, the biplots (Figures 2-5) present the outliers. Our source analyses indicate that outliers most commonly occur when one variable has a much greater value when compared to other variables studied. This is caused by e.g., specific temporary environmental conditions.

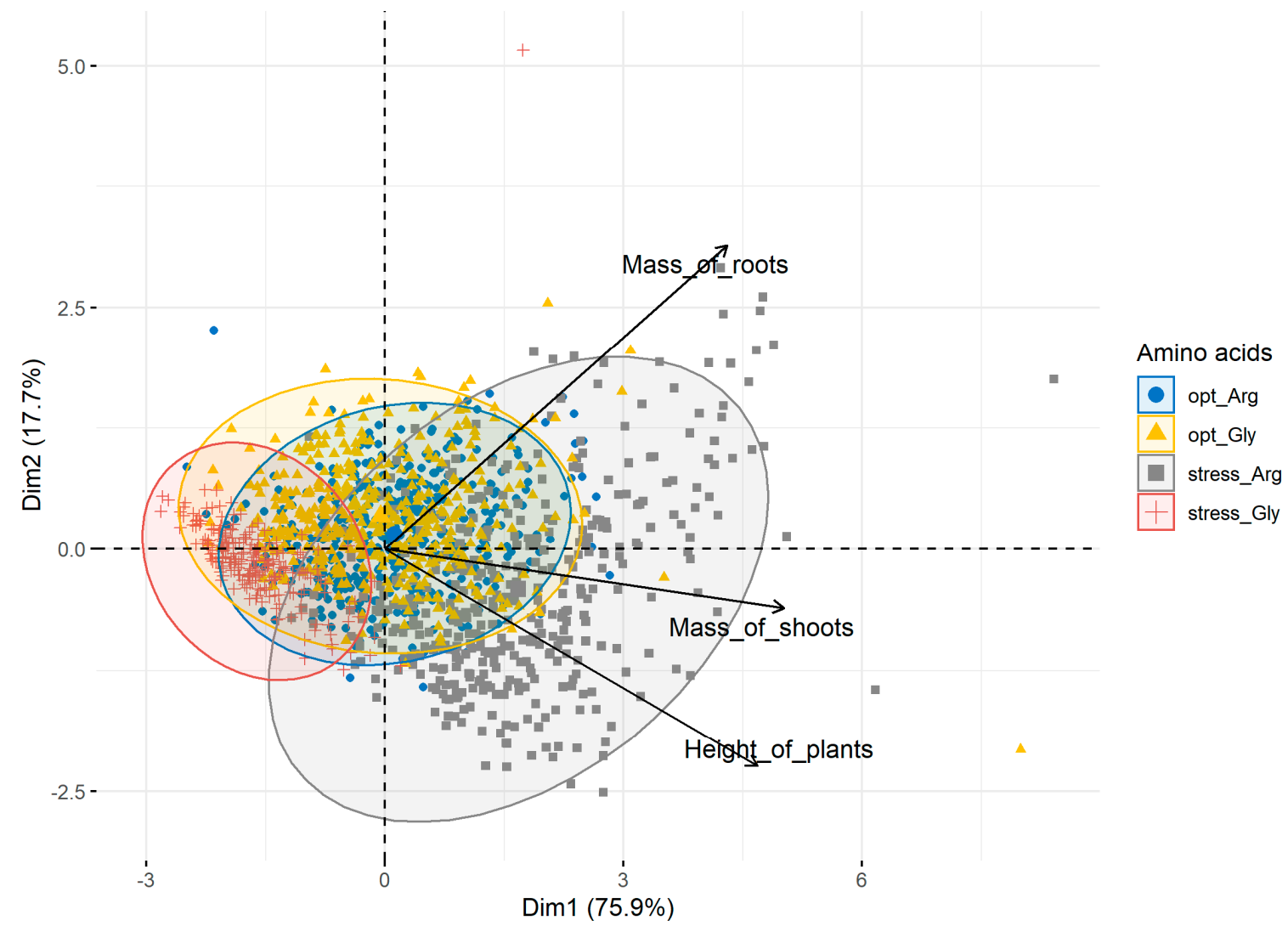

Figure 5. PCA biplot of the fresh mass of roots, the fresh mass of shoots and the height of plants. Cases are grouped by the amino acid (L-Arginine and Glycine) and the conditions applied (optimal and stress).

\section{Discussion}

Research on the effects of exogenous amino acid application on plants focuses on three methods of application: seed, foliar, and culture medium treatments. The aim of our study, which also involved seed pre-treatment, was mainly to determine the concentration of amino acids for further research based on the length and number of lateral roots. However, the study does not precisely indicate the likely course of the further growth and development of maize obtained from seeds soaked in the solutions of the amino acids analysed. Nevertheless, numerous studies by other authors indicate that pre-treating seeds with amino acids may positively influence the subsequent development of plants, especially under stress conditions. In a study that was conducted by Rasheed et al. [41], seed pre-treatments with the amino acid proline proved beneficial in improving the germination and growth of seedlings under optimal and sub-optimal conditions. Arginine pre-treatment significantly increased the germination percentage and germination rate of Pistacia vera in low temperature conditions as compared to untreated 
samples, according to Nasibi et al. [42]. In our studies with soaked seeds, where there were no stress conditions, it was shown that the seeds pre-treated with amino acids germinated at the same rate as the seeds from the control, and both L-Arginine (L-Arg) and Glycine (Gly) increased the length of the root and lateral roots. However, in the case of L-Arg, the average amino acid concentrations were $0.2 \mathrm{mM}$, $0.3 \mathrm{mM}$, and $0.6 \mathrm{mM}$. In the case of Gly, both the lowest $(0.006 \mathrm{mM}$ to $0.06 \mathrm{mM})$ and the very high ( $2 \mathrm{mM}$ to $9 \mathrm{mM}$ ) concentrations were good for the root system. Moreover, Nejadalimoradi et al. [16] showed that pre-treatment Arg with concentrations $1 \mathrm{mM}$ and $5 \mathrm{mM}$ significantly increased the total biomass of sunflower plants. The results of our research are consistent with those that were obtained by Zeid et al. [43], who observed that arginine pre-treatment promoted the growth parameters of bean plants. Nejadalimoradi et al. [16] showed that pre-treatment Arg $1 \mathrm{mM}$ and $5 \mathrm{mM}$ increased the length of plants, but that the greatest plant height was obtained in control plants that were pre-treated with arginine $1 \mathrm{mM}$. Sotiropoulos et al. [21], who studied the effectiveness of increasing concentrations of arginine of the culture medium, observed that the number of shoots of apple per explant increased.

In our study, while the differences in the effects of the two amino acids on the germination and growth of radicle were small and only concerned the concentrations being tested, significant differences appeared after foliar application and following the introduction of the stress factor. For plants growing under optimal conditions, a beneficial effect of L-Arg was noted on both the mass of shoots and roots, while, for plants growing under stress, a beneficial effect of L-Arg was only noted on the mass of roots. However, this was a significant increase of up to $100 \%$. What is undoubtedly interesting about the results of our study is that L-Arg did not have any impact on the height and biomass of the maize growing under stress conditions, although other researchers observed a contrary effect. A case in point is a study by Hassanein et al. [22], who proved that foliar spraying of wheat shoots with arginine and putrescine (1.25 and $2.5 \mathrm{mM}$ ) before temperature significantly increased the fresh and dry mass and water content and arginine treatments were more effective than putrescine in this respect. Yagi and Al-Abdulkareem [44], who presumed that arginine might have helped in the synthesis of polyamines, which are associated with the adaptation to stressful environments, also observed the beneficial effect of Arginine on plants that were exposed to stress factors. The application of arginine before exposing wheat plants to high stress temperature increased the amino acids while decreasing the NH4+ (very toxic) contents when compared with the untreated plants that were only exposed to high temperature [41]. The obtained data were supported by Kesba [45], who reported that L-arginine treatments stimulated plant growth (grape) by enhancing the levels of arginine, aspartic, glutamic, proline, and methionine. It is difficult to compare our research with studies by other authors, as it has been proven that under stress conditions accumulation of polyamines, whose precursors include L-Arginine, depends on the plant species or even cultivar. In some species, polyamine is produced in response to stress, whereas, in others, there is not even a decrease in endogenous polyamines [14,46]. Likewise, every species may react differently to the amount of the amino acid supplied. Moreover, the dose-concentration of the amino acid-may have various effects, depending on the plant development phase at the time of application.

Nassar et al. [47] found that increasing concentrations of Arg significantly increased the growth parameters and promoted the growth and increased the fresh and dry mass in beans. In our study, no linear relationship between the increased concentrations and the increase in the trait examined was observed and this concerned both Arg and Glycine. Our study showed that the impact on the height of maize treated with L-Arg was small, regardless of the conditions. The differences in plant height either ranged from a few to several percent or the height was the same as in the control plants. The most beneficial effect on this trait was L-Arg concentrations from $0.3 \mathrm{mM}$ and higher. However, Qados [35] reported that spraying mung bean with arginine $1.25,2.5$, and $5 \mathrm{mM}$ significantly reduced the plant height of mung bean plants and increasing the arginine concentration gradually reduced the plant height. Mohseni et al. [48] recorded that the exogenous application of Arginine at $0.5 \mathrm{mM}$ also affected the size of the fruit of strawberry and increased the number of achenes of primary and secondary fruit of that plant. 
The present study revealed that Gly had little effect on plants growing under optimal conditions. On the other hand, when applied at certain concentrations under stress conditions, it even had a negative effect on the weight of maize shoots and roots. These results support the findings of Yang et al. [24], who reported that Glycine significantly reduced the fresh and aboveground weights when compared to control lettuce, but that the highest exogenous concentration of glycine (18 $\mathrm{mM})$ significantly increased the total polyphenol content of the lettuce leaves. Other researchers note that the effect of Gly might be dependent on the nitrogen content of the medium. Forsum et al. [49] point out that, when compared to nitrogen deficiency, exogenous glycine supply increases the production of biomass in Arabidopsis plants. The appropriate concentration of glycine significantly enhanced the levels of antioxidants, as compared to lettuce supplied with nitrate [24]. In addition, although this does not come within the scope of our study, there are studies showing that the effect of amino acids on the growth of plants might vary, depending on the individual susceptibility to the variety to a stress factor [50].

The research described points to a non-consistent reaction of maize to the amino acids studied. Even though the two amino acids are essential to plants, they perform different functions. Arginine is involved in the synthesis of polyamines, whose anti-oxidative effect has been confirmed in numerous scientific studies. Glycine, on the other hand, as the main amino acid in the synthesis of chlorophyll, plays an important role in photosynthesis. However, it is arginine that serves as the main focus in most of the scientific reports on the effect of amino acids on plants under stress (salt, temperature, water). In our study, we wanted to demonstrate that exogenous glycine application might also significantly impact the growth and development of maize (although the impact was mainly negative). We also attempted to analyse the effect of amino acids in a large number of concentrations. This proved fruitful, as we showed significant differences in the effects of L-Arg and Gly, depending on their concentration.

This study might also have a practical application. There are numerous products on the market (fertilizers, biostimulators) that contain a complex of amino acids, including L-Arg and Gly, intended for use in e.g. maize, especially under conditions of expected stress. Basic research on the effects of different amino acids on arable crops might contribute considerably to the better use of these products or to the verification of the need to use them in the current composition.

\section{Conclusions}

From the above-mentioned results, it could be concluded that the effects of the two amino acids on maize plants are different. L-Arg had an incomparably higher effect on the crop. These differences were particularly pronounced following foliar application. In conditions where the plants were deprived of the stress factor, a very good effect of L-Arg on increasing the mass of shoots was observed at concentrations of $0.3 \mathrm{mM}$ and $2.0 \mathrm{mM}$, whereas the mass of roots was stimulated by concentrations of $0.3 \mathrm{mM}, 2.0 \mathrm{mM}$, as well as by $3 \mathrm{mM}$. Under stress conditions, six out of 10 concentrations revealed a stimulating effect on maize roots, and $3.0 \mathrm{mM}$ and $6 \mathrm{mM}$ increased the weight of maize roots, even by $100 \%$. It was proven that Gly applied at concentrations of $(0.2 \mathrm{mM}$ to $2 \mathrm{mM})$ has a negative effect on the fresh mass of the crop under stress. In conclusion, the exogenous use of L-Arginine is beneficial for the growth and development of maize plants, especially under stress conditions. Glycine does not exhibit biostimulative properties, but it could probably be beneficial at higher concentrations. Our study indicates that L-Arg is useful in maize protection against the dynamically changing temperature stressor; however, more detailed researches are needed on this subject. As for future research, field studies analysing the effect of L-Arg on subsequent growth and yielding of maize would be very valuable.

Author Contributions: Conceptualization, K.M. and R.K. (Roman Kierzek); methodology, K.M. and W.M.; software, I.S.; formal analysis, J.K.; investigation, R.K. (Roman Krawczyk); writing - original draft preparation, K.M.; writing - review and editing, K.M. and I.S. All authors have read and agreed to the published version of the manuscript.

Funding: This research was funded by the Polish Ministry of Science and Higher Education program Project No. HET-08/1.3.3. 
Acknowledgments: This study was the part of statutory activity of the Institute of Plant Protection-National Research Institute in Poland. The project 'Evaluation of biological activity of plant growth regulators and biostimulants in cereals' (No. HET-08/1.3.3) was supported by the Polish Ministry of Science and Higher Education.

Conflicts of Interest: The authors declare no conflict of interest.

\section{References}

1. Hasanuzzaman, M.; Nahar, K.; Fujita, M. Extreme Temperature Responses, Oxidative Stress and Antioxidant Defense in Plants. In Abiotic Stress-Plant Responses and Applications in Agriculture; InTech: Rijeka, Croatia, 2013. [CrossRef]

2. Tollenaar, M.; Lee, E.A. Yield potential, yield stability and stress tolerance in maize. Field Crops Res. 2002, 75, 161-169. [CrossRef]

3. Bafeel, S.O.; Ibrahim, M.M. Antioxidants and accumulation of $\alpha$-tocopherol induce chilling tolerance in Medicago sativa. Int. J. Agric. Biol. 2008, 10, 593-598.

4. Wahid, A.; Shabbir, A. Induction of heat stress tolerance in barley seedlings by pre-sowing seed treatment with glycinebetaine. Plant Growth Regul. 2005, 46, 133-141. [CrossRef]

5. Wahid, A.; Gelani, S.; Ashraf, M.; Foolad, M.R. Heat tolerance in plants: An overview. Environ. Exp. Bot. 2007, 61, 199-223. [CrossRef]

6. Liu, J.H.; Wang, W.; Wu, H.; Gong, X.; Moriguchi, T. Polyamines function in stress tolerance: From synthesis to regulation. Front. Plant Sci. 2015, 6, 827. [CrossRef] [PubMed]

7. Winter, G.; Todd, C.D.; Trovato, M.; Forlani, G.; Funck, D. Physiological implications of arginine metabolism in plants. Front. Plant Sci. 2015, 6, 534. [CrossRef]

8. Ahmad, I.; Basra, S.M.A.; Wahid, A. Exogenous application of ascorbic acid, salicylic acid and hydrogen peroxide improves the productivity of hybrid maize at low temperature stress. Int. J. Agric. Biol. 2014, 16, 825-830.

9. Afzal, I.; Noor, M.A.; Bakhtavar, M.A.; Ahmad, A.; Haq, Z. Improvement of spring maize performance through physical and physiological seed enhancements. Seed Sci. Technol. 2015, 43, 238-249. [CrossRef]

10. Aroca, R.; Irigoyen, J.J.; Sánchez-Díaz, M. Drought enhances maize chilling tolerance. II. Photosynthetic traits and protective mechanisms against oxidative stress. Physiol. Plantarum 2003, 117, 540-549. [CrossRef]

11. Ruelland, E.; Zachowski, A. How plants sense temperature. Environ. Exp. Bot. 2010, 69, 225-232. [CrossRef]

12. Bahuguna, R.N.; Jagadish, K.S. Temperature regulation of plant phenological development. Environ. Exp. Bot. 2015, 111, 83-90. [CrossRef]

13. Nasibi, F.; Heidari, T.; Asrar, Z.; Mansoori, H. Effect of arginine pre-treatment on nickel accumulation and alleviation of the oxidative stress in Hyoscyamus niger. J. Soil Sci. Plant Nutr. 2013, 13, 680-689. [CrossRef]

14. Liu, J.H.; Kitashiba, H.; Wang, J.; Ban, Y.; Moriguchi, T. Polyamines and their ability to provide environmental stress tolerance to plants. Plant Biotechnol. 2007, 24, 117-126. [CrossRef]

15. Ali, Q.; Anwar, F.; Ashraf, M.; Saari, N.; Perveen, R. Ameliorating effects of exogenously applied proline on seed composition, seed oil quality and oil antioxidant activity of maize (Zea mays L.) under drought stress. Int. J. Mol. Sci. 2013, 14, 818-835. [CrossRef]

16. Nejadalimoradi, H.; Nasibi, F.; Kalantari, K.M.; Zanganeh, R. Effect of seed priming with L-arginine and sodium nitroprusside on some physiological parameters and antioxidant enzymes of sunflower plants exposed to salt stress. Agric. Commun. 2014, 2, 23-30.

17. Gill, S.S.; Tuteja, N. Reactive oxygen species and antioxidant machinery in abiotic stress tolerance in crop plants. Plant Physiol. Biochem. 2010, 48, 909-930. [CrossRef] [PubMed]

18. Moller, I.M.; Jensen, P.E.; Hansson, A. Oxidative modifications to cellular components in plants. Annu. Rev. Plant Biol. 2007, 58, 459-481. [CrossRef]

19. Calvo, P.; Nelson, L.; Kloepper, J.W. Agricultural uses of plant biostimulants. Plant Soil 2014, 383, 3-41. [CrossRef]

20. Ashraf, M.; Foolad, M. Roles of glycine betaine and proline in improving plant abiotic stress resistance. Environ. Exp. Bot. 2007, 59, 206-216. [CrossRef]

21. Sotiropoulos, T.E.; Dimassi, K.N.; Therios, I.N. Effects of L-arginine and L-cysteine on growth, and chlorophyll and mineral contents of shoots of the apple rootstock EM 26 cultured in vitro. Biol. Plantarum 2005, 49, 443-445. [CrossRef] 
22. Hassanein, R.A.; El-Khawas, S.A.; Ibrahim, S.K.; El-Bassiouny, H.M.; Mostafa, H.A.; Abdel-Monem, A.A. Improving the thermo tolerance of wheat plant by foliar application of arginine or putrescine. Pak. J. Bot. 2013, 45, 111-118.

23. Venkatesh, J.; Park, S.W. Role of L-ascorbate in alleviating abiotic stresses in crop plants. Bot. Stud. 2014, 55, 38. [CrossRef]

24. Yang, X.; Cui, X.; Zhao, L.; Guo, D.; Feng, L.; Wei, S.; Zhao, C.; Huang, D. Exogenous glycine nitrogen enhances accumulation of glycosylated flavonoids and antioxidant activity in lettuce (Lactuca sativa L.). Front. Plant Sci. 2017, 8, 2098. [CrossRef]

25. Xiaochuang, C.; Chu, Z.; Lianfeng, Z.; Junhua, Z.; Hussain, S.; Lianghuan, W.; Qianyu, J. Glycine increases cold tolerance in rice via the regulation of $\mathrm{N}$ uptake, physiological characteristics, and photosynthesis. Plant Physiol. Biochem. 2017, 112, 251-260. [CrossRef]

26. WaqasWaqas, M.A.; Khan, I.; Akhter, M.J.; Noor, M.A.; Ashraf, U. Exogenous application of plant growth regulators (PGRs) induces chilling tolerance in short-duration hybrid maize. Environ. Sci. Pollut. Res. 2017, 24, 11459-11471. [CrossRef]

27. Matysiak, K.; Miziniak, W.; Kaczmarek, S.; Kierzek, R. Herbicides with natural and synthetic biostimulants in spring wheat. Cienc. Rural 2018, 48,1-10. [CrossRef]

28. Moradtalab, N.; Weinmann, M.; Walker, F.; Höglinger, B.; Ludewig, U.; Neumann, G. Silicon improves chilling tolerance during early growth of maize by effects on micronutrient homeostasis and hormonal balances. Front. Plant Sci. 2018, 9, 420. [CrossRef]

29. Ghezzi, P.; Bonetto, V. Redox proteomics: Identification of oxidatively modified proteins. Proteomics 2003, 3, 1145-1153. [CrossRef]

30. du Jardin, P. Plant biostimulants: Definition, concept, main categories and regulation. Sci. Hortic. 2015, 196, 3-14. [CrossRef]

31. Rai, V.K.; Sharma, U.D. Amino acids can modulate ABA induced stomatal closure, stomatal resistance and K+ fluxes in Vicia faba leaves. Beitr. Biol. Pflanz. 1991, 66, 393-405.

32. Rai, V.K. Role of amino acids in plant responses to stresses. Biol. Plant 2002, 45, 481-487. [CrossRef]

33. Hassanein, R.A.; Hassanein, A.A.; Haider, A.S.; Hashem, H.A. Improving salt tolerance of Zea mays L. plants by presoaking their grains in glycine betaine. Aust. J. Basic Appl. Sci. 2009, 3, 928-942.

34. Rafiee, H.; Mehrafarin, A.; Qaderi, A.; Kalate, J.S.; Naghdi, B.H. Phytochemical, agronomical and morphological responses of pot marigold (Calendula officinalis L.) to foliar application of bio-stimulators (bioactive amino acid compounds). J. Med. Plants 2013, 12, 48-61.

35. Qados, A.M.S.A. Effect of arginine on growth, nutrient composition, yield and nutritional value of mung bean plants grown under salinity stress. Nat. Sci. 2010, 8, 30-42.

36. Nasibi, F.; Yaghoobi, M.M.; Kalantari, K.M. Effect of exogenous arginine on alleviation of oxidative damage in tomato plant underwater stress. J. Plant Interac. 2011, 6, 291-296. [CrossRef]

37. Greaves, J.A. Improving suboptimal temperature tolerance in maize-the search for variation. J. Exp. Bot. 1996, 47, 307-323. [CrossRef]

38. Cholakova-Bimbalova, R.; Vassilev, A. Effect of chilling stress on the photosynthetic performance of young plants from two maize (Zea mays) hybrids. CBU Int. Conf. Proc. 2017, 5, 1118-1123. [CrossRef]

39. Bano, S.; Aslam, M.; Saleem, M.; Basra, S.M.A.; Aziz, K. Evaluation of maize accessions under low temperature stress at early growth stages. J. Anim. Plant Sci. 2015, 25, 392-400.

40. R Core Team. R: A Language and Environment for Statistical Computing; R Foundation for Statistical Computing: Vienna, Austria, 2019; Available online: https://www.R-project.org/ (accessed on 24 September 2019).

41. Rasheed, R.; Wahid, A.; Farooq, M.; Hussain, I.; Basra, S.M. Role of proline and glycinebetaine pretreatments in improving heat tolerance of sprouting sugarcane (Saccharum sp.) buds. Plant Growth Regul. 2011, 65, 35-45. [CrossRef]

42. Nasibi, F.; Barand, A.; Kalantari, K.M.; Rezanejad, F. The effect of arginine pretreatment on germination, growth and Physiological parameters in the increase of low temperature tolerance in Pistacia vera L. in vitro culture. J. Agric. Crop Sci. 2013, 5, 1918-1925.

43. Zeid, I.M. Effect of arginine and urea on polyamines content and growth of bean under salinity stress. Acta Physiol. Plant. 2009, 31, 65-70. [CrossRef]

44. Yagi, M.I.; Al-Abdulkareem, S.S. Effects of exogenous arginine and uric acid on Eruca sativa Mill grown under saline conditions. J. Sci. Technol. 2006, 7, 1-11. 
45. Kesba, H.H. Effect of amino acids foliar application on Meloigyne incognita and biochemical alterations in grape roots. Bull. Fac. Agric. Cairo Univ. 2005, 56, 617-629.

46. Liu, J.H.; Nada, K.; Honda, C.; Kitashiba, H.; Wen, X.P.; Pang, X.M.; Moriguchi, T. Polyamine biosynthesis of apple callus under salt stress: Importance of the arginine decarboxylase pathway in stress response. J. Exp. Bot. 2006, 57, 2589-2599. [CrossRef]

47. Nassar, A.H.; El-Tarabily, K.A.; Sivasithamparam, K. Growth promotion in bean (Phaseolus vulgaris L.) by a polyamine-producing isolate of Streptomyces griseoluteus. Plant Growth Regul. 2003, 40, 97-106. [CrossRef]

48. Mohseni, F.; Pakkish, Z.; Panahi, B. Arginine impact on yield and fruit qualitative characteristics of strawberry. Agric. Conspec. Sci. 2017, 82, 19-26.

49. Forsum, O.; Svennerstam, H.; Ganeteg, U.; Näsholm, T. Capacities and constraints of amino acid utilization in Arabidopsis. New Phytol. 2008, 179, 1058-1069. [CrossRef]

50. Sobahan, M.A.; Akter, N.; Ohno, M.; Okuma, E.; Hirai, Y.; Mori, I.C.; Nakamura, Y.; Murata, Y. Effects of exogenous proline and glycinebetaine on the salt tolerance of rice cultivars. Biosci. Biotechnol. Biochem. 2012, 76, 1568-1570. [CrossRef]

(C) 2020 by the authors. Licensee MDPI, Basel, Switzerland. This article is an open access article distributed under the terms and conditions of the Creative Commons Attribution (CC BY) license (http://creativecommons.org/licenses/by/4.0/). 